\title{
Characterization of a Novel Synapse-specific Protein. I. Developmental Expression and Cellular Localization of the F1-20 Protein and mRNA
}

\author{
Rui Sousa, Nancy Hrinya Tannery, Shibin Zhou, and Eileen M. Lafer \\ Department of Biological Sciences, University of Pittsburgh, Pittsburgh, Pennsylvania 15260
}

\begin{abstract}
A molecular description of the nerve terminal will be required to understand synaptic function fully. The goals of this study were to contribute toward such a description by characterizing a novel synapse-specific protein. A monoclonal antibody library was screened for antibodies to synaptic proteins. The antibodies were then used to isolate cDNA clones by expression screening. Here we report a detailed characterization of the protein reactive with monoclonal antibody F1-20. Immunohistochemical and biochemical analyses revealed that the $F 1-20$ protein is synapse associated. Western blot analyses revealed that the F1-20 protein is a brainspecific polypeptide with an apparent molecular weight on SDS-PAGE of 190,000 Da. Northern blot analyses indicated that probes generated from an F1-20 cDNA clone hybridize to a single brain-specific mRNA of approximately 4.8 kilobases. In situ hybridization experiments demonstrated that F1-20 mRNA expression is neuronal specific. Northern and Western blot analyses indicated that F1-20 mRNA levels increase abruptly at postnatal day 4 and protein levels increase abruptly at postnatal day 7 . This corresponds to a period of active synaptogenesis and synaptic maturation in the mouse CNS. We characterized the neuroanatomical distribution of the F1-20 protein by immunohistochemistry, and of the F1-20 mRNA by in situ hybridization. We found that the F1-20 mRNA and protein are expressed nonuniformly in brain. Variation in the expression of the F1-20 protein is complex and reveals patterns also exhibited by probes directed against other synapse-associated molecules. The highest levels of $F 1-20$ protein are found in the cortically organized regions of the brain. The highest levels of F1-20 mRNA are found in long-distance projection neurons. There is also variation in the expression of F1-20 mRNA between different classes of large output neuron, as well as extensive variation in the expression of F1-20 mRNA between different nuclear groups.
\end{abstract}

\footnotetext{
Received June 17, 1991; revised Jan. 7, 1992; accepted Jan. 9, 1992.

This work was supported by NIH Grant RO1 NS29051 to E.M.L. and by a March of Dimes Basal O'Connor Starting Scholar Award to E.M.L. Seed funds were made available from NIMH Grant 5 P50 MH30915 to the Mental Health Clinical Research Center for the Study of Affective Disorders of the University of Pittsburgh. R.S. was supportcd by NSF and Andrew Mcllon predoctoral fellowships. We gratefully acknowledge the contributions of Dr. Donald DeFranco and Beverly Hamilton to the Northern blot analyses.

Correspondence should be addressed to Eileen M. Lafer, A505 Langley Hall Department of Biological Sciences, University of Pittsburgh, Pittsburgh, PA 15260
} Copyright (C) 1992 Society for Neuroscience $0270-6474 / 92 / 122130-14 \$ 05.00 / 0$
The premise that proteins that are expressed exclusively at synapses contribute to their specialized function has fueled the efforts of many laboratories to provide a molecular description of the nerve terminal (reviewed in Sudhof and Jahn, 1991; Trimble et al., 1991). Nerve terminal-associated molecules that have been identified include synapsin I a,b/protein I a,b (De Camilli et al., 1983a-c; Sudhof et al., 1989b), p65/synaptotagmin (Matthew et al., 1981; Fournier and Trifaro, 1988), tor70 (Carlson and Kelly, 1983), SV2 (Buckley and Kelly, 1985), p29 (Pfeffer and Kelly, 1985; Baumert et al., 1990), synaptophysin/p38 (Jahn et al., 1985; Wiedenmann and Franke, 1985), mediatophore (Israel et al., 1986), synapsin II a,b/protein III a,b (Browning et al., 1987; Sudhof et al., 1989b), VAMP-1,2/synaptobrevin (Trimble et al., 1988, 1990; Baumert et al., 1989; Elferink et al., 1989; Sudhof et al., 1989a), synuclein (Maroteaux et al., 1988), VAT-1 (Linial et al., 1989), NT75 (Ritchie et al., 1989), synaptoporin (Knaus et al., 1990), SVAPP-120 (Bahler et al., 1991), and SNAP-25 (Oyler et al., 1989; Geddes et al., 1990).

The early studies on synaptic molecules concentrated primarily on their identification and isolation. The more mature studies have now reached the point where insights are being made into the mechanism of synaptic function (Llinas et al., 1985; Thomas ct al., 1988, 1990; Sudhof et al., 1989b; Perin et al., 1990; Hahn et al., 1991; Petrenko et al., 1991).

Monoclonal antibodies (MAbs) offer the ability to detect a rare synapse-associated protein by a rapid, sensitive, immunohistochemical screen. The antibodies can then be used to screen cDNA expression libraries for the isolation of cDNA clones. Consequently, we screened a MAb library (Sousa et al., 1990) for antibodies to synaptic proteins. Here we report the characterization of the protein reactive with MAb F1-20. In this article, we present evidence that the F1-20 protein is a novel, synapse-associated, neuronal-specific protein expressed in a pattern coincident with synaptogenesis and synaptic maturation. We also characterize the extensive variation in expression of both the F1-20 mRNA and the F1-20 protein. In the accompanying article (Zhou et al., 1992), we have deduced the amino acid sequence for the F1-20 protein through the isolation and sequencing of overlapping cDNA clones. This led to a number of predictions regarding biochemical properties of the F1-20 protein that were then tested. Evidence is presented that the F120 mRNA has two alternatively spliced isoforms, that the F120 protein is a substrate for calcium-dependent proteolysis that is specifically inhibited by calpain inhibitors in vitro, and that the F1-20 protein is phosphorylated in vivo. 


\section{Materials and Methods}

Antibodies. The preparation of MAb F1-20 was described previously (Sousa et al., 1990). Fractionated rat cerebral cortex was chosen as our source of immunogen, since we were concerned that it would be difficult to produce antibodies against antigens isolated from mice in mice, our preferred organism for hybridoma work. The antibodies were characterized on mouse tissue, and cDNA clones were isolated from mouse cDNA libraries, since we plan to study the genes and proteins further using transgenic mice. The heterologous antibody control was a MAb raised against a $100 \mathrm{kDa}$ Escherichia coli Z-DNA binding protein (Lafer et al., 1988) that does not cross-react with murine brain tissue. While not shown, data were only considered meaningful when no staining was observed with this negative control. The anti-synaptophysin MAb was clone SY 38 (Wiedenmann and Franke, 1985) obtained from Boehringer Mannheim.

Immunohistochemistry. Immunohistochemistry was performed as described in Sousa et al. (1990).

In situ hybridization. In situ hybridization was carried out as described in Sousa et al. (1989).

Western blot analyses. Whole tissues were homogenized at $4^{\circ} \mathrm{C}$ in a Dounce homogenizer in $66 \mathrm{~mm}$ Tris (pH 6.8), $10 \%$ glycerol, $2 \%$ SDS, $5 \% 2$-mercaptoethanol, $1 \mathrm{~mm} p$-methylsulfonyl fluoride $(15 \mathrm{ml}$ buffer/ gm of tissue) followed by boiling for $5 \mathrm{~min}$. The homogenate was cleared of insoluble material by centrifugation at $100,000 \mathrm{~g}_{\max }$ for $60 \mathrm{~min}$ at $4^{\circ} \mathrm{C}$, and loaded directly onto $7.5 \%$ polyacrylamide SDS Phastgels (Pharmacia). The gels were run on the Pharmacia Phastsystem followed by unidirectional diffusion blotting for $20 \mathrm{~min}$ at $70^{\circ} \mathrm{C}$ in the Phastsystem apparatus. The rest of the procedure was carried out at room temperature. Blots were blocked in $10 \mathrm{~mm}$ Tris, $\mathrm{pH} 8.0,150 \mathrm{~mm} \mathrm{NaCl}, 0.5 \%$ Tween 20 (TBST) containing 3\% BSA for $30 \mathrm{~min}$. Filters were incubated in the primary antibody for $30 \mathrm{~min}$, followed by three $10 \mathrm{~min}$ washes in TBST. Filters were incubated in an alkaline phosphatase-labeled secondary antibody (Promega Biotec) for $30 \mathrm{~min}$, followed by $310 \mathrm{~min}$ washes in TBST. Filters were then incubated in a substrate solution of $330 \mu \mathrm{g} / \mathrm{ml}$ nitro blue tetrazolium, $165 \mu \mathrm{g} / \mathrm{ml}$ 5-bromo-4-chloro-3-indolyl phosphate, $100 \mathrm{~mm}$ Tris (pH 9.5), $100 \mathrm{~mm} \mathrm{NaCl}, 5 \mathrm{~mm} \mathrm{MgCl}{ }_{2}$ until appropriate color development occurred.

Subcellular fractionation. Synaptosomes were prepared by the method of Huttner et al. (1983). Mouse cerebral cortex was homogenized in $0.32 \mathrm{~m}$ sucrose, 4 mm HEPES, pH 7.3 (buffered sucrose). The homogenate was spun at $800 \times g$ for $10 \mathrm{~min}$ to generate a pellet (P1) and supernatant (S1). The supernatant was then spun at $9200 \times g$ for 15 min to generate a supernatant (S2) and pellet (P2). The pellet was resuspended in buffered sucrose and spun at $10,200 \times g$ for $15 \mathrm{~min}$ to generate supernatant $\left(\mathbf{S} 2^{\prime}\right)$ and pellet $\left(\mathrm{P}^{\prime}\right)$. Pellet $\mathrm{P} 2^{\prime}$ was referred to as the "well-washed crude synaptosomal fraction" by Huttner et al. (1983). The pellet $\left(\mathbf{P} 2^{\prime}\right)$ was resuspended in buffered sucrose and transferred to a glass-Teflon homogenizer. This suspension was lysed by adding $9 \mathrm{vol}$ of ice cold $\mathrm{dH}_{2} \mathrm{O}$ and homogenizing with three up-and-down strokes at $3000 \mathrm{rpm}$. The $\mathrm{P}^{\prime}$ lysate was adjusted to $7.5 \mathrm{~mm}$ HEPES-NaOH, $\mathrm{pH}$ 7.2 , and kept on ice $30 \mathrm{~min}$. It was then centrifuged for $20 \mathrm{~min}$ at 25,000 $\times g$ to yield a lysate pellet (LP1) and a lysate supernatant (LS1). LS1 was centrifuged for $2 \mathrm{hr}$ in a Beckman Ti70 rotor at $165,000 \times g$, to generate a pellet (LP2) and a supernatant (LS2). LS2 was concentrated in an Amicon Minicon concentrator to $25 \times$.

Northern blot analyses. Total RNA was isolated from tissues by the RNAzol method (CINNA/BIOTECX) of Chomczynski and Sacchi (1987). Ten micrograms of RNA were loaded per lane and electrophoresed on $1.0 \%$ agarose gels containing formaldehyde (Lehrach et al., 1977), transferred to GeneScreen membranes (New England Nuclear), and fixed to the filters by UV cross-linking (Church and Gilbert, 1984). The Bluescript phagemid containing the 1.2 kilobase (kb) F1-20 cDNA clone was used as a template to prepare ${ }^{32} \mathrm{P}$-labeled DNA probes by the oligonucleotide random-priming technique according to the method of Feinberg and Vogelstein $(1983,1984)$. Specific activities of $1-2 \times 10^{9}$ $\mathrm{cpm} / \mu \mathrm{g}$ of DNA were routinely obtained. Hybridization and posthybridization washes were performed at $43^{\circ} \mathrm{C}$ and $50^{\circ} \mathrm{C}$, respectively (Amasino, 1986). Approximately equal amounts of total RNA (determined by measurement of UV absorbance) were loaded in different lanes of single gels for purposes of comparison of F1-20 mRNA expression in various tissues or developmental stages. Examination of ethidium bromide-stained gels showed sharp bands corresponding to $18 \mathrm{~S}$ and $28 \mathrm{~S}$ rRNA that were of equal intensity in different lanes. As a further control to demonstrate the presence of hybridizable mRNA in all tissue and developmental stage samples, all blots were rehybridized with a probe for a ubiquitous mRNA (chicken $\beta$-actin).

\section{Results}

The F1-20 protein is synapse associated

The following experiments were designed to demonstrate that the antigen being recognized by the F1-20 MAb is a synapseassociated protein. Immunohistochemical as well as biochemical analyses were utilized. Figure 1 shows a section through mouse cerebellar cortex immunohistochemically stained with the F1-20 antibody and lightly counterstained with cresyl violet. Figure $1 A$ shows this section photographed in green light allowing visualization of both the cresyl violet and the brown peroxidase product while Figure $1 B$ shows the section in blue light allowing visualization of the brown peroxidase product only. Specific immunoreactivity is distributed in the cerebellar molecular layer and the synaptic glomeruli within the granule cell layer in a fine punctate pattern. Immunoreactivity is excluded from cellular somata and white matter, and in the molecular layer, the dendrites of the Purkinje cells appear outlined by immunohistochemical staining. Such features have been previously interpreted as being indicative of proteins specifically associated with nerve terminals or synapses (Bloom et al., 1979; De Camilli et al., 1983a; Jahn et al., 1985; Wiedenmann and Franke, 1985). High-magnification light microscopy of F1-20 immunoreactivity in various brain regions shows that the punctate pattern of staining is consistently present. In regions with lower synapse densities the punctate pattern is clearer and neuronal cell bodies can sometimes be observed to be surrounded by a number of fine intensely immunoreactive points (Fig. $2 C$, $D$ ). Examination of the cerebellar granule cell layer reveals numerous strongly staining puncta $\sim 0.5-1.0 \mu \mathrm{m}$ in size within the glomerulus (Fig. 2E-G).

Further evidence at the light microscope level for the association of the F1-20 protein with synapse-rich areas can be obtained from examination of staining in other cortically organized regions. When immunoreactivity in the cerebral cortex is cxamincd (Fig. 2A), outlining of ncuronal ccll bodics and pyramidal cell apical dendrites is clear. In addition staining is observed to become stronger in the neuronal cell-poor layer 1 . Many neurons in the other layers of the cerebral cortex send their dendrites into layer 1 , where they ramify extensively to make multiple synaptic contacts. Consequently, layer 1 is relatively synapse rich. The heightened immunoreactivity in layer 1 is therefore consistent with an association of the F1-20 protein with synaptic zones. In the olfactory bulb (Fig. $2 B$ ) immunoreactivity is seen in the large olfactory glomeruli where the incoming olfactory nerve fibers establish synapses with the apical dendrites of the mitral and tufted cells. Within the internal granule cell layer, islands of strong staining are surrounded by clusters of unstained granule cell bodies. No staining of mitral cell bodies or periglomerular cells in the glomerular layer is observed. There is a relatively low level of staining in the external plexiform layer (EPL), a cell-poor dendritic plexus.

Biochemical evidence for association of the F1-20 protein with synaptic regions was obtained from Western blot analysis of cellular subfractions prepared from mouse brain cerebral cortex (Fig. 3). Western blot analysis with the F1-20 MAb of total brain protein had revealed a single immunoreactive band with an apparent molecular weight of 190,000 Da (Fig. 4C). Characterization of synaptophysin by others (Jahn et al., 1985; Wiedenmann and Franke, 1985) had demonstrated that it was an 
Figure 1. The main features of the immunohistochemical staining pattern of the F1-20 MAb are illustrated in this lightly cresyl violet-counterstained section through the mouse cerebellar cortex. $A$ was photographed in green light so that both the cresyl violet and immunohistochemical stains are visible. $B$ was photographed in blue light to demonstrate clearly the density due to the immunohistochemical stain alone. The F1-20 protein is seen to be excluded from cellular somata $(P$, Purkinje cell layer) and white matter fiber tracts $(W)$ but is concentrated in the molecular layer $(M)$ and the synaptic glomeruli $(S G)$ within the granule cell layer $(G)$ (synaptic glomeruli form irregularly shaped regions surrounded by granule cell bodies staining darkly with cresyl violet in $A$ ). The F1-20 protein is also observed to be distributed in a fine punctate pattern throughout the molecular layer and within the synaptic glomeruli. The fine punctate pattern is clearest in $A$, because the image in $B$ was photographed in blue light, which greatly enhances the contrast for the brown peroxidase product, resulting in overexposure and blurring of the fine structural details of the distribution of the peroxidase product. Scale bar, 50 $\mu \mathrm{m}$.
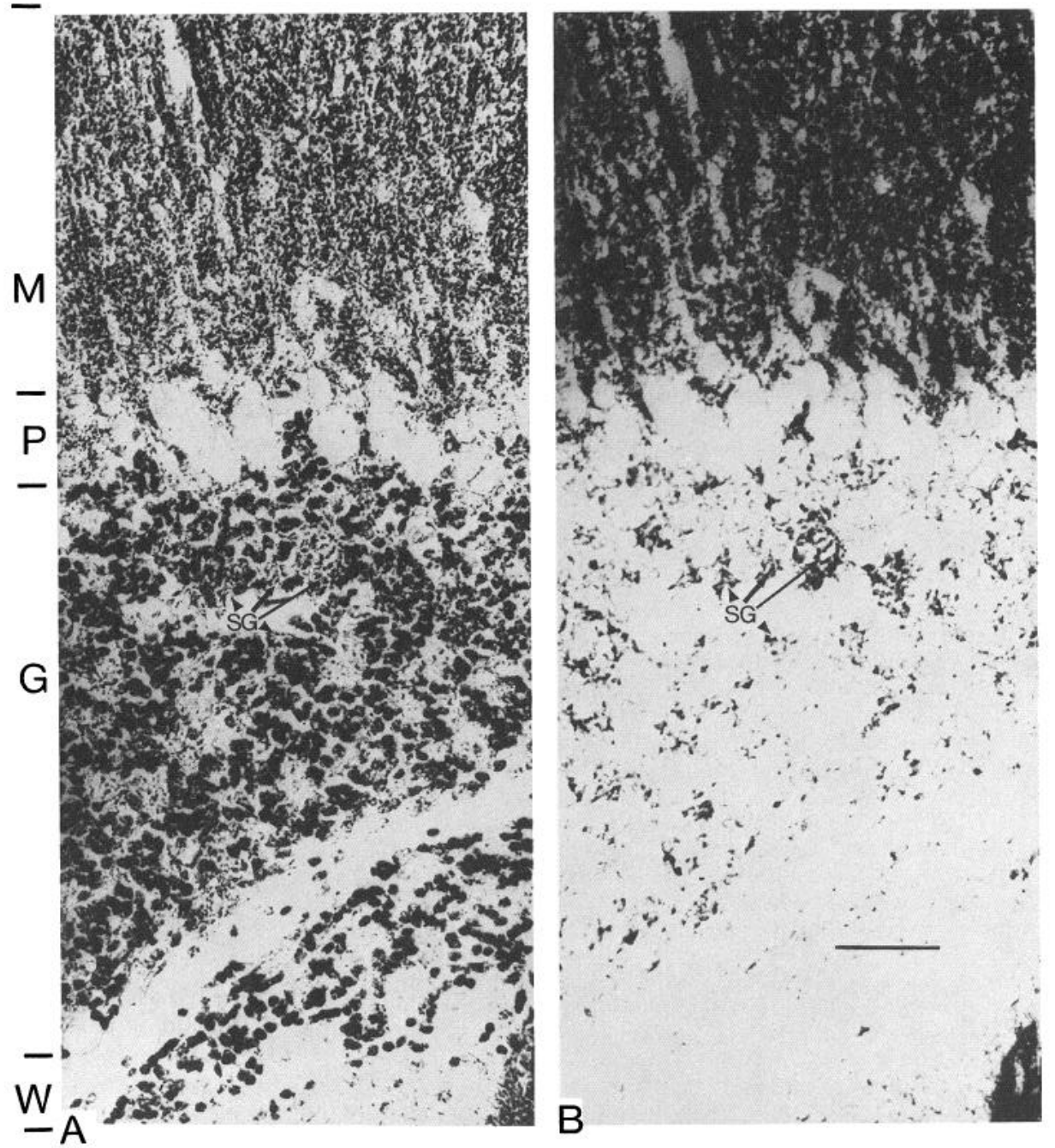

intrinsic membrane protein of synaptic vesicles, rendering it a suitable marker for the biochemical fractionation. We utilized the fractionation of Huttner et al. (1983). Mouse cerebral cortices were homogenized in buffered sucrose $(\mathrm{H})$. The crude homogenate was spun at $800 \times g$ to generate the supernatant (S1). S1 was spun at $9200 \times g$ to generate the crude synaptosomal pellet P2, which was resuspended in buffered sucrose and pelleted at $10,200 \times g$ to generate the well-washed crude synaptosomal pellet $\mathrm{P} 2{ }^{\prime}$. P2' was then lysed by hypo-osmotic shock, and spun at $25,000 \times g$ to generate the supernatant LS1. LS1 contains the soluble proteins of the synaptosome, as well as the synaptic vesicles. The synaptic vesicles were then pelleted from LS1 by centrifugation at $165,000 \times g$. To illustrate visually the fact that the specific activity (concentration of F1-20/unit total protein) of the F1-20 protein increased throughout the fractionation, equal quantities of each successive fraction were loaded onto the SDS polyacrylamide gel. The concentration of the F1-20 protein increased up to the synaptosomal lysate LS1 but did not further copurify with the synaptic vesicles. Synaptophysin, as expected, continued to purify with the synaptic vesicles.

We carried out an exhaustive search for conditions that would reveal the ultrastructural location of the F1-20 antigen by immunoelectron microscopy utilizing both monoclonal and polyclonal antibodies reactive with the F1-20 protein. We were un- successful at finding conditions that would preserve both the tissue ultrastructure and F1-20 immunoreactivity, We were able to demonstrate the labeling of synaptic vesicles by anti-synaptophysin antibodies, indicating that our inability to detect the F1-20 protein at the ultrastructural level was not due to technical mishandling of the tissues.

\section{The F1-20 protein is expressed tissue specifically in brain}

If the F1-20 protein has a nervous system-specific function, then we expect its expression to be restricted to nervous tissue. We tested this by examining a variety of tissues for expression of the F1-20 protein by Western blot analysis, and for expression of the F1-20 mRNA by Northern blot analysis. The Western blot was stained with the F1-20 MAb. The Northern blot was hybridized with a ${ }^{32} \mathrm{P}$-labeled F1-20 cDNA clone, which is described in the accompanying article (Zhou et al., 1992). The F120 cDNA probe labels a single brain-specific RNA of approximately $4.8 \mathrm{~kb}$ (Fig. $4 A$ ). This RNA was just detectable in brain RNA after a $12 \mathrm{hr}$ exposure, while no hybridization could be observed to RNAs from liver, kidney, heart, spleen, or lung even after a $10 \mathrm{~d}$ exposure (shown). As a positive control, the blot was stripped and reprobed with a $\beta$-actin probe (Fig. $4 B$ ) that labeled a single RNA in all tissues. Figure 4, $C$ and $D$, shows Western blots of total protein isolated from the same set of tissues stained with either the F1-20 MAb $(C)$ or india ink $(D)$. 

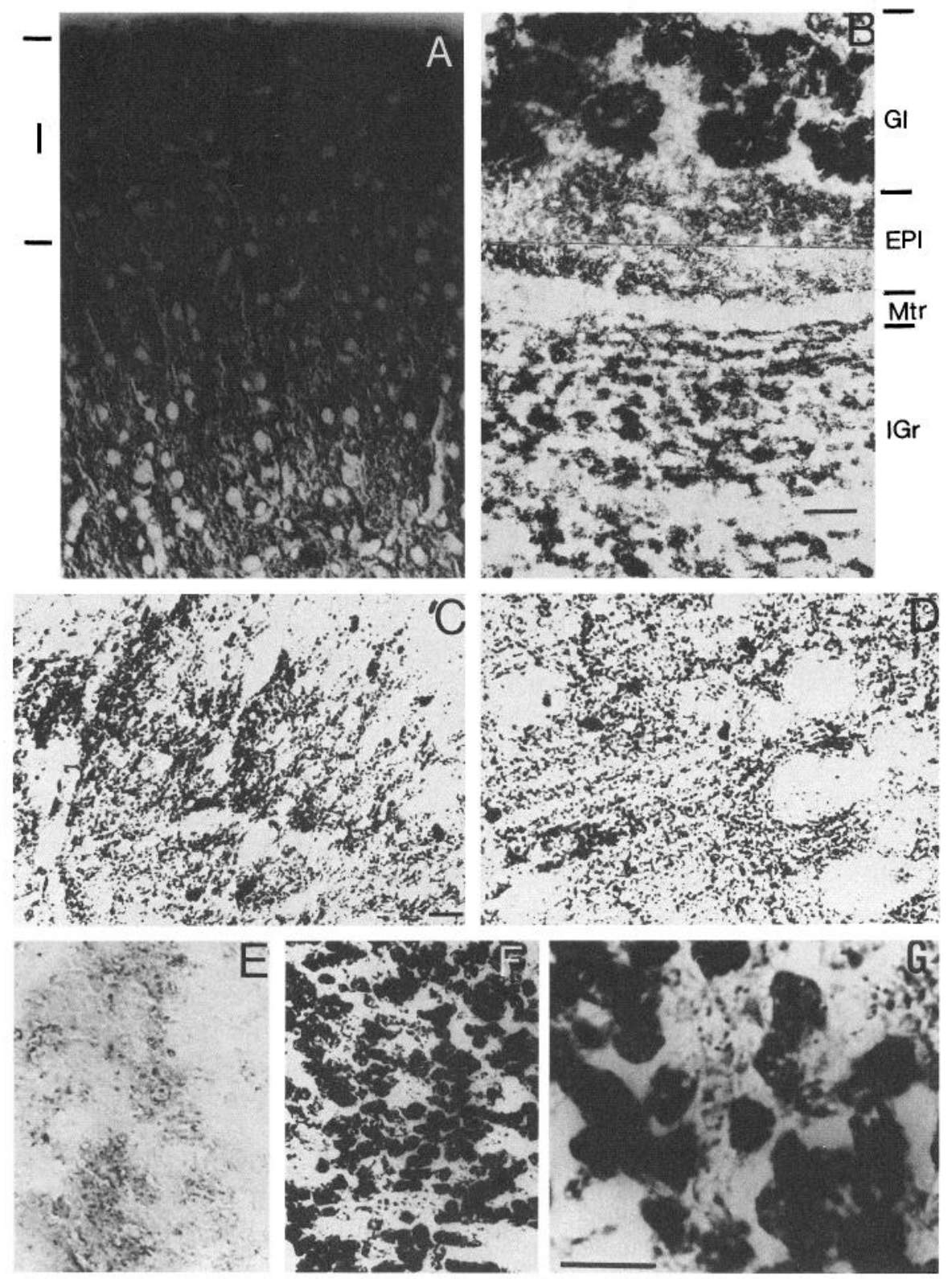

Figure 2. Representative examples of the immunohistochemical staining pattern of the F1-20 MAb reveal that the F1-20 protein is consistently excluded from cell bodies and dendrites, and is distributed throughout the neuropil in the punctate pattern typical of nerve terminal-associated proteins. $A$, Cerebral cortex. B, Main olfactory bulb (Mtr, mitral cell layer; $G l$, synaptic glomeruli; $I G r$, internal granule cell layer; $E P l$, external plexiform layer). $C$, Hippocampal hillus. $D$, Cerebral frontal cortex. $E$, Cerebellar granule cell layer (immunostained only). $F$, Cerebellar granule cell layer (granule cells counterstained with cresyl violet). $G$, High-magnification view of a single synaptic glomerulus within the cerebellar granule cell layer (granule cells counterstained with cresyl violet) reveals numerous strongly staining puncta $\sim 0.5-1.0 \mu \mathrm{m}$ in size within the glomerulus. Scale bars: $B$, $100 \mu \mathrm{m}$ for $A$ and $B ; C, 25 \mu \mathrm{m}$ for $C$ $F ; G, 25 \mu \mathrm{m}$.
An immunoreactive band with an apparent molecular weight of $190 \mathrm{kDa}$ was detected in the protein extract from the brain tissue but not in any of the other extracts. In subsequent experiments performed identically to the ones shown here, we could not detect the F1-20 protein in muscle or adrenal medulla (data not shown).

\section{The F1-20 protein is expressed exclusively by neurons}

The synaptic distribution of the F1-20 protein (Figs. 1-3) and tissue-specific expression of the F1-20 mRNA and protein (Fig. 4) suggested that the F1-20 protein and mRNA would be expressed exclusively by neuronal cells. We tested this by examining the localization of F1-20 mRNA in areas of the brain containing both neuronal and non-neuronal cell types utilizing in situ hybridization. Sections probed with an ${ }^{35} \mathrm{~S}$-labeled antisense transcript of the F1-20 cDNA are photographed in dark field to illustrate clearly the hybridization signal or bright field (giemsa counterstained) to reveal the cells in the same field. For comparison, dark-field views of sections of similar regions in the brain probed with an ${ }^{35} \mathrm{~S}$-labeled antisense transcript of glucocorticoid hormone receptor (GR) cDNA (Sousa et al., 1989) are shown. We have previously demonstrated that glucocorticoid hormone receptor mRNA is expressed in choroid plexus, meninges, and both neuronal and glial cells (Sousa et al., 1989).

The strong expression of F1-20 mRNA in the neuronal cells of the cerebellar cortex is evident (Fig. $5 D, E$ ), as well as its absence from the meninges at the exterior of the cerebellar folia. In contrast, GR is expressed strongly in the meninges (Fig. $5 F$ ). The absence of F1-20 mRNA in choroid plexus is well illustrated in Figure 5, $A$ and $B$. While the area of the brain shown adjacent to the choroid plexus is not rich in neuronal cells, weak hybridization with the F1-20 probe is observed over neurons (indicated by short bars). Hybridization observed over the choroid plexus with the GR probe contrasts with the pattern observed for the F1-20 probe (Fig. $5 C$ ). Figure $5, I-K$, illustrates the absence of F1-20 mRNA from glial cells located within fiber 
$\begin{array}{lllll}\text { H } & \text { S1 } & \text { P2' } & \text { LS1 } & \text { LP2 }\end{array}$

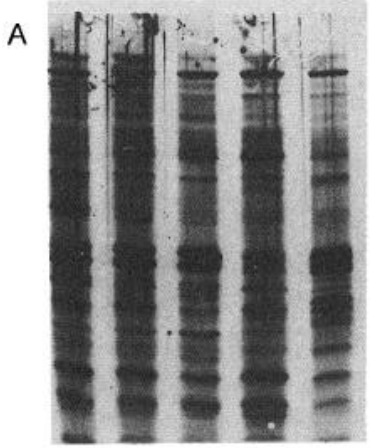

B

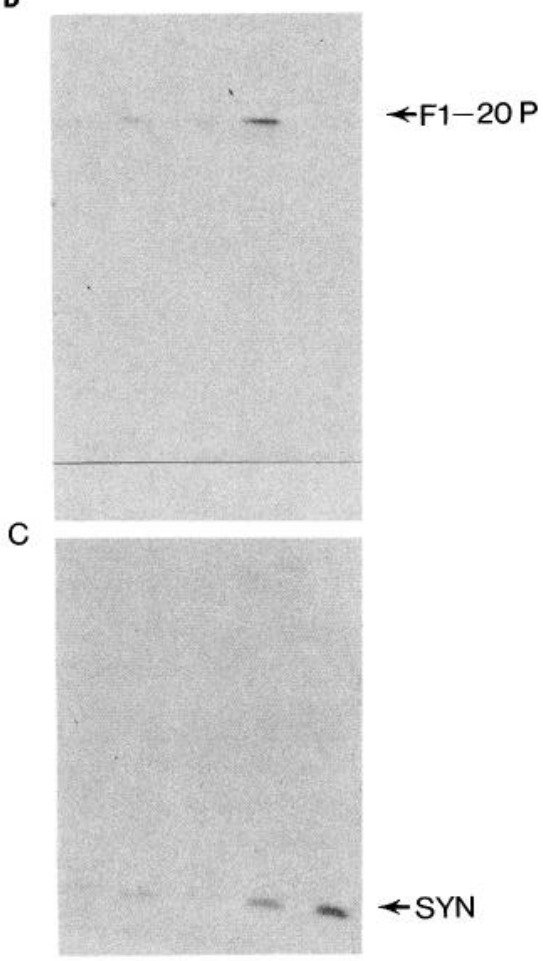

Figure 3. A comparative Western blot analysis of subcellular fractions of mouse brain analyzed for total protein ( $A$, stained with india ink), the $F 1-20$ protein ( $B$, stained with the F1-20 MAb), and synaptophysin ( $C$, stained with SY38). Lanes labeled $H, S 1, P 2^{\prime}, L S 1$, and $L P 2$ correspond respectively to the fractions generated by the procedure of Huttner et al. (1983), which were electrophoresed on $7.5 \%$ polyacrylamide SDS gels and blotted onto nitrocellulose. Pellet P2' was referred to by Huttner et al. (1983) as the "well-washed crude synaptosomal fraction." After hypotonic lysis of the crude synaptosomal fraction, the lysate was spun for $20 \mathrm{~min}$ at $25,000 \times g$ to yield a lysate pellet $(L P I)$ and a lysate supernatant $(L S 1) . L S 1$ was centrifuged for $2 \mathrm{hr}$ at 165,000 $\times g$, to generate a pellet $(L P 2)$ and a supernatant $(L S 2)$. Shown on the gel are $L S I$, which contains the soluble proteins and synaptic vesicles, and $L P 2$, which contains the pelleted synaptic vesicles. Equal concentrations of total protein of the indicated fractions were loaded in each lane.

tracts. Both the GR probe and the F1-20 probe show strong hybridization within the anterodorsal nucleus, and the hybridization within this nucleus is distributed in large, irregularly spaced clusters indicative of hybridization to large neurons (Fig. $5 I, J)$. The GR probe also shows hybridization within the fimbrium hippocampus, but in this case the hybridizing cells are smaller and distributed with more regular spacing [this is particularly evident in lower-magnification views where a larger field can be seen and the pattern of GR probe hybridization to small cells distributed in a regular array throughout fiber tracts is evident (Fig. $5 K$ )]. Such a pattern provides unambiguous demonstration of glial cell expression of GR mRNA (Sousa et al., 1989). In contrast, hybridization of the F1-20 probe to cells lying within the fimbrium hippocampus (or other fiber tracts) is never seen. Demonstration of neuronal specificity within gray matter where glial cells lie closely intermixed with neurons is more problematical. Figure 5, $G$ and $H$, shows a field within the anterior cingulate cortex hybridized with the F1-20 cDNA probe. F1-20 mRNA can be seen to be present in the cells containing a pale staining soma surrounding an intensely stained nucleus (neurons). Cells with glial morphology (i.e., the small moon-shaped cells indicated by arrowheads and the small, round, strongly staining cells) show no hybridization. In all areas examined, we were unable to detect hybridization to cells with such morphology while the GR probe was found to hybridize to such cells.

\section{Expression of the F1-20 protein is developmentally regulated in a pattern coincident with active synaptogenesis and synaptic maturation}

We found by immunohistochemistry with the F1-20 MAb that the F1-20 protein was not expressed in the CNS of 11.5 and $14.5 \mathrm{~d}$ mouse embryos, or newborn animals. Expression of F120 protein was not detected immunohistochemically at postnatal day 3 but was detected at postnatal day 7 . Because the first two postnatal weeks in mice constitute a period of active synaptogenesis (Bloom, 1972; Vaughn, 1989) and synaptic maturation (Kosik et al., 1989), we were prompted to analyze carefully the developmental regulation of F1-20 mRNA and protein during this critical developmental period using Northern (Fig. $6 A, B$ ) and Western (Fig. $6 C$ ) blot analyses. Only small amounts of F1-20 mRNA were detected prior to postnatal day 4 , at which point an abrupt increase to apparently adult levels of F1-20 mRNA is observed (Fig. 6A). As a positive control, the blot was stripped and reprobed with a $\beta$-actin probe (Fig. $6 B$ ), which labeled $\beta$-actin RNA from all of the developmental stages examined. A sharp increase in the expression of F1-20 protein to apparently adult levels was observed between postnatal days 6 and 7 (Fig. 6C), corroborating our immunohistochemical observations.

\section{The F1-20 protein is expressed nonuniformly in brain}

We considered that understanding the neuroanatomical distribution of the F1-20 protein and mRNA would contribute to our long-term goal of determining the role of the F1-20 protein in synaptic function. Consequently, we set out to characterize the neuroanatomical distribution of the F1-20 protein by immunohistochemistry, and of the F1-20 mRNA by in situ hybridization. A series of mouse brain sagittal sections were immunohistochemically stained with the F1-20 MAb. A representative section is shown in Figure $7 \mathrm{~A}$. Table 1 summarizes the observed variation in immunoreactivity.

Cortically arranged areas of the brain show the strongest immunoreactivity (Fig. 7 $A$, Table 1 ). The entire mes- and rhomboencephalon (and deep cerebellar nuclei) show uniformly low immunoreactivity, but higher-magnification views reveal that the cell bodies of many neurons (particularly the larger neurons) within these regions are outlined by strong immunoreactivity. 

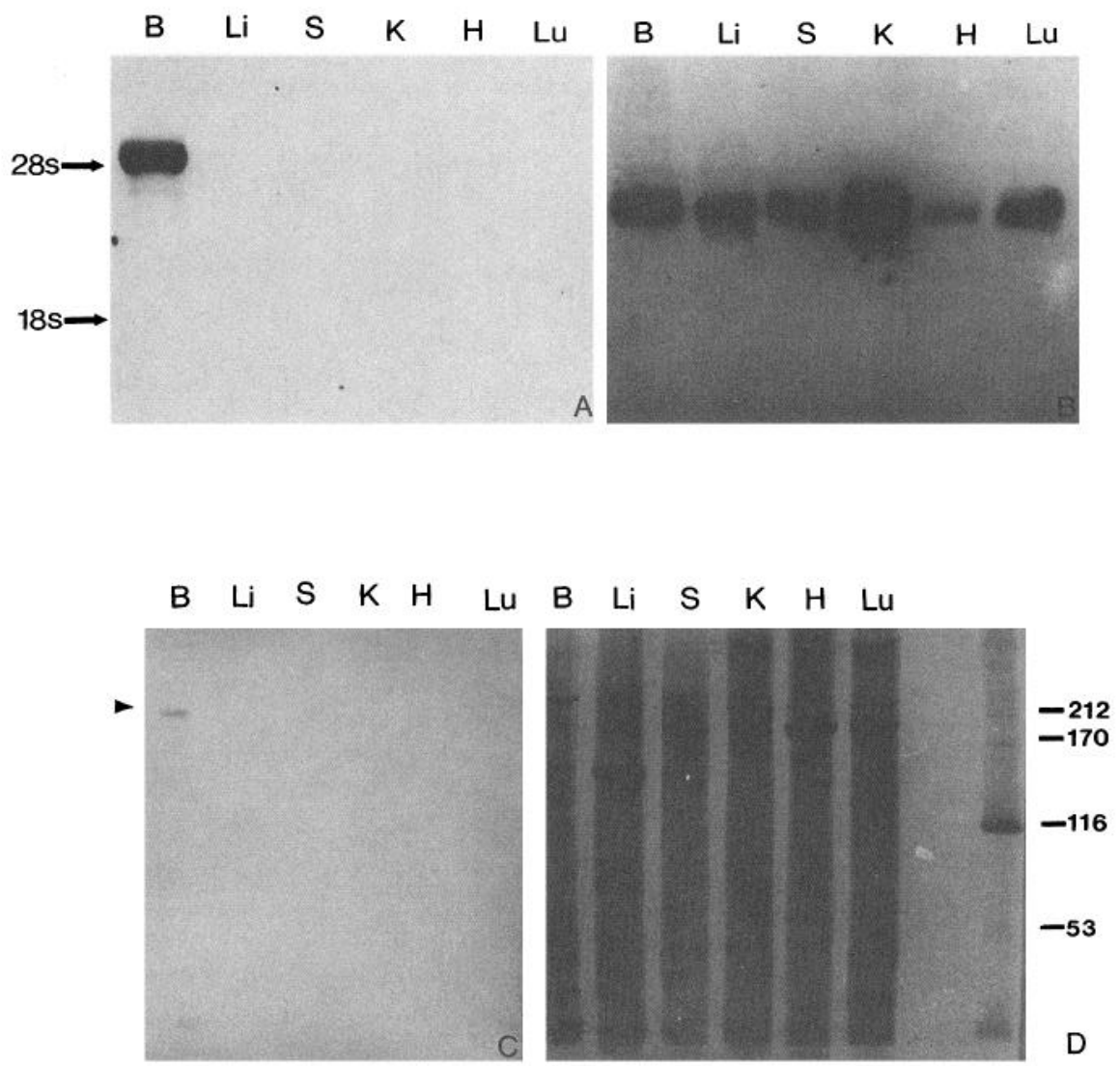

Figure 4. The F1-20 mRNA and protein are expressed tissue specifically. Northern $(A$ and $B)$ and Western $(C$ and $D)$ blots were probed either with a ${ }^{32} \mathrm{P}$ labeled F1-20 cDNA fragment $(A)$, a ${ }^{32} \mathrm{P}$-labeled actin cDNA fragment $(B)$, or the F1-20 MAb $(C)$ or were stained for total protein with india ink $(D)$. Total protein or total RNA (10 $\mu \mathrm{g} /$ lane) was prepared from a variety of tissues as indicated: brain $(B)$, liver $(L i)$, spleen $(S)$, kidney $(K)$, heart $(H)$, and lung $(L u)$. In $A$, the positions of the $28 \mathrm{~S}$ and $18 \mathrm{~S}$ rRNAs are indicated and a $10 \mathrm{~d}$ exposure of the autoradiogram is shown. In $C$, the F1-20 MAb is observed to react with a single polypeptide with an apparent molecular weight of 190,000 Da (arrowhead). (Note: band at the bottom of the gel is the dye marker Pyronin Y.) In $C$ and $D$, fivefold more protein was loaded in the non-brain versus brain lanes. The limit of detection of the F120 protein by this Western analysis protocol is $1 / 20$ th of the amount loaded in this experiment.
However, this concentration of staining is limited to the immediate vicinity of the neuronal cell bodies, and the levels of staining within the neuropil of the mes- and rhomboencephalon are low. The lowest levels of immunoreactivity are observed in the components of the tripartite pallidum: the globus pallidus (including the ventral pallidum), the entopeduncular nucleus, and the substantia nigra pars reticulata.

F1-20 immunohistochemistry reveals complex variations in expression that are also revealed by probes for other synaptic molecules (Fig. 7B-F). Within the hippocampus, F1-20 immunoreactivity is distributed in a laminated pattern (Fig. $7 B$ ). Two lamina are evident in the dentate area molecular layer. A thin intensely immunoreactive layer is seen to lie immediately superficial to the dentate granule cell layer. AChE histochemistry also shows intense staining of this layer, which contains the nerve terminals of hippocampal hilar neurons that send their excitatory axons ipsi- and contralaterally back to this sharply delimited lamina (Paxinos and Watson, 1986). A second, thicker, and less intensely immunoreactive layer is present in the superficial area of the molecular layer and corresponds to the termination region of the excitatory perforant path. Finally, while immunoreactivity is strong throughout the radiatum and oriens layers, in the $\mathrm{CA} 3$ region the staining in the radiatum layer is laminated with weak staining evident in the one-third to one-half of this region, which is superficial to the CA3 pyramidal cell layer. The weakly staining region of the CA3 radiatum layer corresponds to the dentate granule cell mossy fiber termination zone (the lucidum layer). Interestingly, synapsin I immunoreactivity was also reported to be similarly laminated in the CA3 (but not CA1 or CA2) radiatum layer but, in contrast to F1-20 immunoreactivity, was relatively stronger in the mossy fiber termination zone (Bloom et al., 1979; De Camilli et al., 1983a). In the striatum, F1-20 immunohistochemistry reveals patches of staining (Fig. 7C,D). Enkephalin, glutamic acid decarboxylase (GAD), and substance P (SP) have all been found to be distributed in patches that correspond to the AChE-poor striosomes (reviewed in Heimer et al., 1985). The thalamic nuclei display extensive variation in F1-20 immunoreactivity (Fig. $7 E, F)$. In general, the dorsal thalamic nuclei show the strongest immunoreactivity with the F1-20 MAb, but a completely consistent pattern along these lines is not present.

Regional variation in F1-20 mRNA content is detected in sagittal mouse brain sections probed with ${ }^{35} \mathrm{~S}$-labeled antisense F1-20 transcripts (Fig. 8A-F). Becasue F1-20 mRNA localizes to cellular somata, areas in which neuronal cells are concentrated such as the olfactory cortex, the cerebellar granule cell layer, the Ammon's horn and dentate gyrus cellular layers, and the olfactory bulb mitral and internal granule cell layers (Fig. $8 M$ ) show the densest hybridization. However, within these regions the levels of F1-20 mRNA are not equal. The densest hybridization is observed in the cellular layers of the olfactory bulb. Within the Ammon's horn neurons, levels of hybridization within the CA2/CA3 neurons are distinctly increased over those in the $\mathrm{CA} 1$ neurons (the border between the $\mathrm{CA} 1$ and $\mathrm{CA} 2 / \mathrm{CA} 3$ regions is indicated by the short bar). The striatum and tripartite pallidum give the lowest levels of hybridization. While the content of F1-20 protein in the mes- and rhomboencephalon and deep cerebellar nuclei is relatively low (Fig. 7), expression of F1-20 mRNA is moderately strong in these areas (i.e., the overall density of hybridization is higher than in the basal ganglia but somewhat lower than in the cerebral cortex). Furthermore, many nuclei within the mes- and rhomboencephalon contain large, 

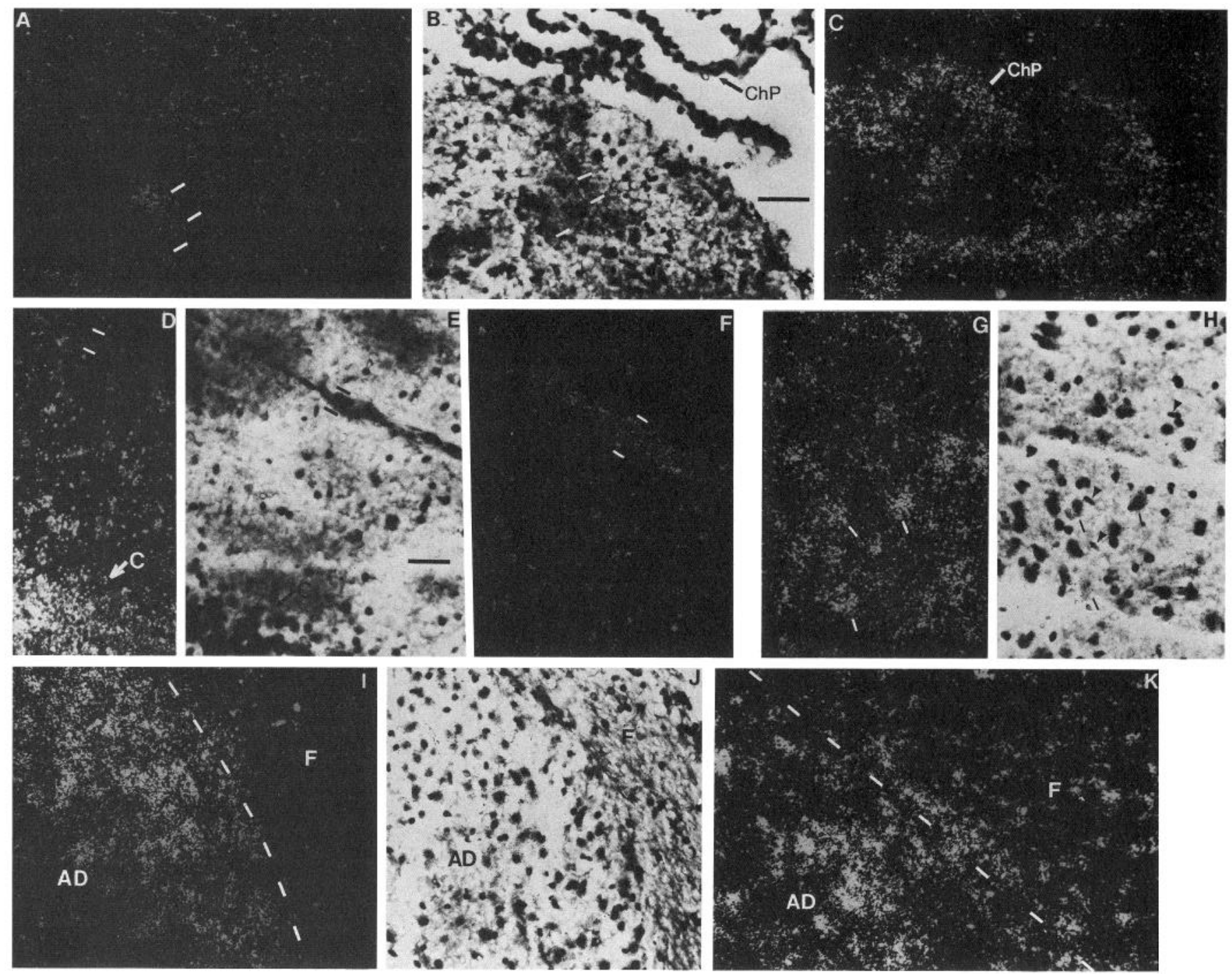

Figure 5. Fl-20 mRNA is expressed exclusively in neuronal cells. $A, D, G$, and $I$ represent dark-field views of mouse brain sections hybridized with ${ }^{35}$-labeled F1-20 antisense transcripts and giemsa counterstained. $B, E, H$, and $J$ represent bright-field views of the respective sections shown in $A, D, G$, and $I$. As a positive control, dark-field views of sections probed with GR antisense transcripts (Sousa et al., 1989a) are presented in $C$, $F$, and $K$. Views are shown that include the choroid plexus $(C h P)(A-C)$, the cerebellar cortex (the cellular layers are labeled with a $C$, and the meninges at the exterior of the cerebellar folia are indicated by short parallel bars) $(D-F)$, a field within the anterior cingulate cortex (large cells with neuronal morphology are indicated by bars; small moon-shaped cells with glial morphology are indicated by arrowheads), the anterodorsal nucleus, and the adjacent hippocampal fimbrium fiber tract (the border is indicated by the broken lines in $I$ and $K$, and is evident from the increased background staining with giemsa in the fiber tract in $J$ ). Scale bars: $B, 100 \mu \mathrm{m}$ for $A-C ; E, 100 \mu \mathrm{m}$ for $D-K$.

strongly hybridizing neurons. These nuclei are evident, on films exposed to sections hybridized with radiolabeled probes, as irregular dark regions within the mes- and rhomboencephalon and deep cerebellar nuclei (dark areas indicated by arrowheads in Fig. 8A-F; note especially the pontine nucleus in Fig. $8 F$ ). Because the poor resolution of film in situ can make distinguishing artifacts from genuine hybridization difficult, these features were confirmed by dark- and bright-field light microscope examination of emulsion-dipped sections probed with ${ }^{35} \mathrm{~S}$-labeled antisense F1-20 transcripts. For example, Figure $8 K$ shows strong hybridization to neurons within the deep cerebellar nucleus (boxed region labeled " $k$ " in Fig. $8 F$ ) while Figure $8 L$ confirms the very strong expresesion of F1-20 mRNA detected in the anterodorsal nucleus by film in situ (boxed region labeled "l" in Fig. $8 \dot{F}$ ).
Light microscopic examination of emulsion dipped sections hybridized with ${ }^{35} \mathrm{~S}$-labeled antisense F1-20 transcripts reveals a wide range of variation of F1-20 mRNA expression in different neuronal cell types. A complete cataloging of this variation has not been carried out, but illustrative comparisons are presented in Figure 9. In general, smaller neurons (granule cells) and medium-sized interneurons express reduced levels of F1-20 mRNA relative to large output neurons even after taking into account differences in expression expected solely on the basis of cell size. For example, Figure $9 D$ shows that density of hybridization of the F1-20 probe in the granule cell layer of the cerebellar cortex is low relative to that observed over the soma of the larger neurons in this figure. Similarly low levels of hybridization are observed in the dentate gyrus granule cell layer (not shown). It is the very high cell densities in these regions that account for 
the strong areal hybridization levels visible in film exposures (Fig. 8) despite the relatively low levels of expression in individual granule cells. Large output neurons are not uniform in their levels of expression. Figure $9 A-G$ compares the levels of expression of F1-20 mRNA in olfactory bulb mitral cells ( $A$ and $E$ ), large telencephalic pyramidal cells $(B$ and $F)$, and cerebellar cortex Purkinje cell $(C, D$, and $G)$, all of which are large output neurons of cortically arranged regions. As a class, mitral cells show the strongest expression of F1-20 mRNA, telencephalic pyramidal cells show intermediate levels, and Purkinje cells show exceptionally low levels. Neurons from nuclear groups also display extensive variation: the particularly strong expression of F1-20 mRNA in the neurons of the anterodorsal thalamic nucleus and pontine nucleus (Fig. 8) have already been noted. Higher-magnification dark-field microscopy illustrates the extent of this variation in neurons of three rhomboencephalic nuclei, the gigantocellular reticular nucleus (Fig. 9H), the reticulotegmental pons nucleus (Fig. 9I), and the oral pontine reticular nucleus (Fig. 9J). Expression in the large neurons of the gigantocellular reticular nucleus is observed to exceed even the levels of expression of F1-20 mRNA in mitral cells.

\section{Discussion}

The association of the F1-20 protein with synapses is supported by both high-resolution light microscopy (Figs. 1, 2) and biochemistry (Fig. 3). Light microscopic examination of tissue sections stained with the F1-20 antibody reveals that the highest concentrations of the protein are present in synapse-rich areas (cerebral cortex layer I, cerebellar cortex molecular layer) or specialized synaptic structures (cerebellar glomeruli, olfactory bulb glomeruli). Specific immunoreactivity is always distributed in a fine punctate pattern, outlining neuronal cell bodies and dendrites. Immunoreactivity is always excluded from white matter and cellular soma. Synapsin I (Bloom et al., 1979; De Camilli et al., 1983a) and synaptophysin (Jahn et al., 1985; Wiedenmann and Franke, 1985) immunoreactivity has also been shown to be distributed in a fine punctate pattern that outlines neuronal cell bodies and dendrites and is excluded from white matter. These features have been interpreted as indicative of proteins specifically associated with nerve terminals or synapses. Within the olfactory bulb, the relatively low level of staining in the EPL is particularly significant. Any membrane-associated protein might show superficial similarity to the pattern of distribution of the F1-20 protein (exclusion from cell bodies, outlining of dendrites). However, the EPL is primarily a dendritic plexus with some tufted cells in its external half. It is therefore cell poor, but as can be seen it shows relatively low levels of immunoreactivity. This low level of immunoreactivity parallels the relative sparseness of axonal-dendritic or axonal-somatic synapses in the EPL relative to the concentration of such synapses in such specialized structures as the olfactory glomeruli.

The biochemical evidence for the association of the F1-20 protein with synapses is also strong. Simply to find a protein in a synaptosomal fraction could represent a minor contaminant, but the fact that the specific activity (concentration of F1-20/ unit total protein) of the F1-20 protein increased throughout the fractionation indicates that the F1-20 protein is enriched in synaptosomes. Upon hypotonic lysis of the synaptosome, the F1-20 protein is released into the soluble fraction, indicating that it is not strongly associated with synaptic vesicles or synaptic plasma membranes. This makes it unlikely that the F120 antigen is the previously described $180 \mathrm{kDa}$ postsynaptic
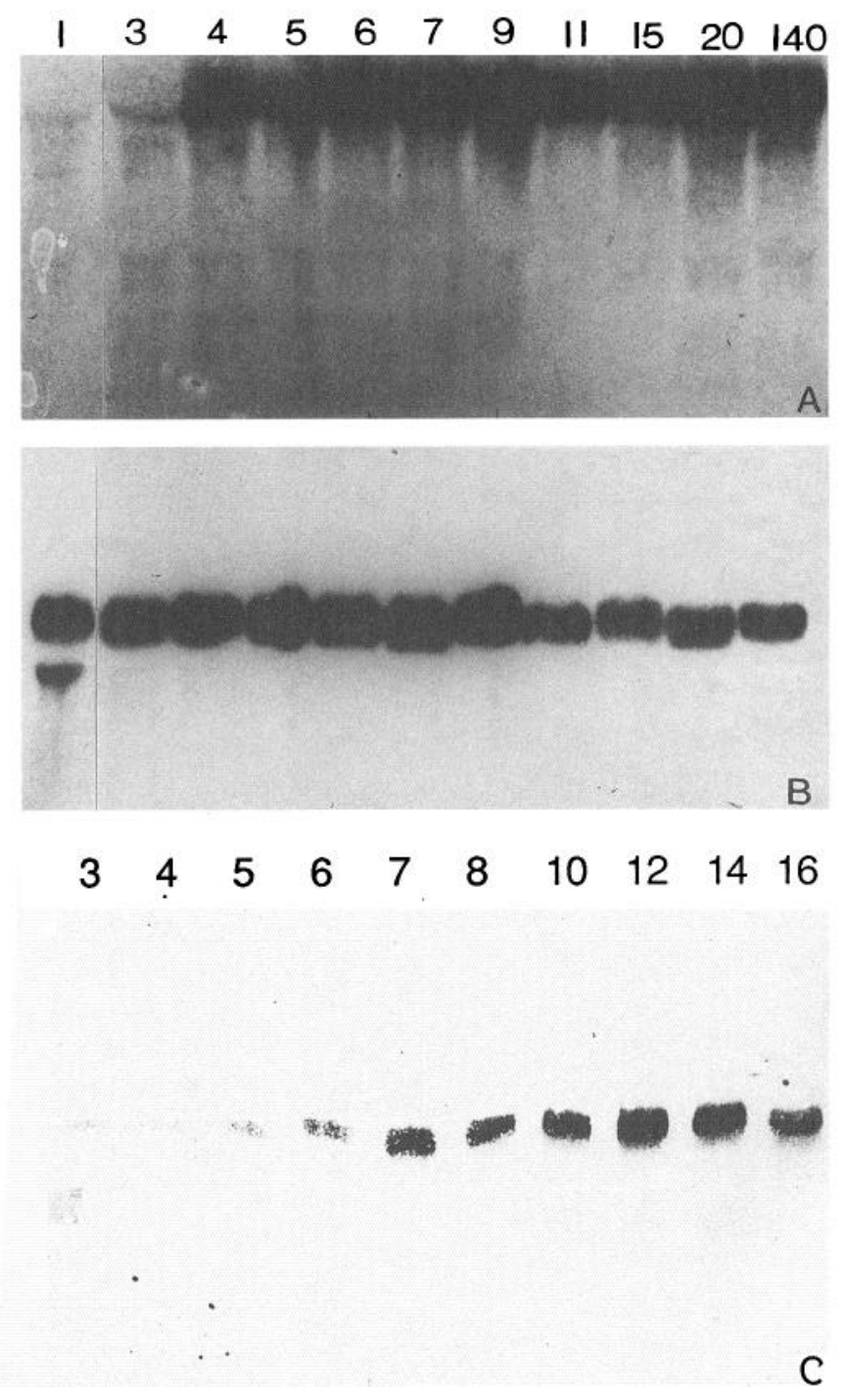

Figure 6. Expression of F1-20 mRNA and protein is developmentally regulated postnatally. Northern $(A$ and $B)$ and Western $(C)$ blots of total mouse brain RNA or protein from the indicated postnatal days were probed with ${ }^{32} \mathrm{P}$-labeled $\mathrm{Fl}-20 \mathrm{cDNA}(A),{ }^{32} \mathrm{P}$-labeled-actin cDNA $(B)$, or F1-20 MAb (C).

density protein (Gurd, 1985). While its molecular weight is similar to the neuronal-specific protein NP185 that is associated with brain clathrin-coated vesicles, the pI of NP185 is reported to be near 6 (Kohtz and Pruszkin, 1988; Su et al., 1991), while in the accompanying article we report the $\mathrm{pI}$ of the F1-20 protein as 3.85 (Zhou et al., 1992). Its apparent molecular weight is not similar to any other previously described synaptic molecules.

Many of the features brought out by immunohistochemistry for the F1-20 protein are also revealed by analyses with probes for other molecules associated with synapses or synaptic transmission (Fig. 7). ${ }^{3} \mathrm{H}-\mathrm{GABA}$ uptake (Walaas, 1983), ${ }^{3} \mathrm{H}-\mathrm{D}-\mathrm{as}-$ partate uptake (Walaas, 1983), synapsin I immunohistochemistry (DeCamilli et al., 1983a-c), and AChE histochemistry (Paxinos and Watson, 1986) all reveal laminar patterns in the hippocampus, though all of these patterns are distinct from the pattern of staining revealed by F1-20 immunohistochemistry. These laminated variations in expression can be quite subtle and complex: F1-20 immunohistochemistry differentiates not 
Table 1. F1-20 immunoreactivity in the mouse brain

\begin{tabular}{|c|c|}
\hline Area & Immunoreactivity \\
\hline \multicolumn{2}{|l|}{ Cerebral cortex } \\
\hline Layer I & +++ \\
\hline Layers II-VI & ++ \\
\hline \multicolumn{2}{|l|}{ Cerebellar cortex } \\
\hline Molecular layer & +++ \\
\hline Granule cell layer synaptic glomeruli & +++ \\
\hline \multicolumn{2}{|l|}{ Main olfactory bulb } \\
\hline Olfactory glomeruli & ++++ \\
\hline External plexiform layer & + \\
\hline Internal granule cell layer (cell-free regions) & +++ \\
\hline \multicolumn{2}{|l|}{ Hippocampus } \\
\hline Molecular layer & $+1++1+++a$ \\
\hline Lacunosum molecular layer & + \\
\hline Radiatum layer & $+++/+^{a}$ \\
\hline Oriens layer & +++ \\
\hline \multicolumn{2}{|l|}{ Striatum } \\
\hline Striosomal & ++ \\
\hline Matrix & + \\
\hline \multicolumn{2}{|l|}{ Thalamus } \\
\hline DLG, MG, VPL, Po, VL, RE, LP & +++ \\
\hline $\mathrm{LD}, \mathrm{AV}, \mathrm{Rt}, \mathrm{ZI}$ & ++ \\
\hline APT, PIL, Sth & + \\
\hline Hypothalamus & + \\
\hline \multicolumn{2}{|l|}{ Tripartite pallidum } \\
\hline Globus pallidus & - \\
\hline Entopeduncular nucleus & - \\
\hline Substantia nigra pars reticulata & - \\
\hline Amygdala & ++ \\
\hline Septum & + \\
\hline Mesencephalon & $+c$ \\
\hline Rhomboencephalon & $+^{c}$ \\
\hline
\end{tabular}

only between the molecular, lacunosum molecular, radiatum, and oriens layers but also distinguishes the termination region of the excitatory perforant path, the lucidum layer, and the termination zone of the hilar neuron axons on the granule cell dendrites. Many molecules associated with synapses or synaptic transmission are also found to exhibit variations in expression between the patch and matrix compartments in the striatum. Enkephalin, GAD, SP, and AChE are examples of such molecules (reviewed in Heimer et al., 1985). Immunohistochemistry for F1-20 also reveals concentration of this protein in patches within the striatum. A final example of this type of variation is found in the thalamic nuclei, which show extensive variation in F 1-20 protein content [e.g., the border between the AChErich reticular thalamic nuclei-zona incerta and $\mathrm{AChE}$-poor ventroposteriolateral nucleus is starkly revealed by F1-20 immunohistochemistry, although the distribution of the F1-20 protein is inversely related to AChE (Paxinos and Watson, 1986)]. While these complex variations in F1-20 protein expression do not reveal its function, we can conclude that they do identify a pattern of expression compartmentalized along borders revealed by probes for other synapse-associated molecules.
Expression of $F 1-20$ protein and $m$ RNA is both tissue specitic and neuronal cell specific. The F1-20 MAb detects a single band with an apparent molecular weight of 190,000 Da on Western blots of extracts prepared from brain tissue. No immunoreactivity is detected in extracts prepared from liver, spleen, kidney, heart, or lung (Fig. 4), or from adrenal medulla or musclc (data not shown). In these experiments, fivefold more total protein was loaded from the non-brain tissue extracts than the brain tissue extracts. In other experiments we have found that the limit of detection of the F1-20 protein using this Western blot protocol with the F1-20 MAb lies at approximately 1/20th the concentration of total brain protein loaded in the blots shown in Figure 4. The F1-20 protein is therefore present in al least 100 -fold greater concentration in brain than in the non-brain tissues analyzed here. Probes prepared from the F1-20 cDNA clone hybridize with a single band of $4.8 \mathrm{~kb}$ on Northern blots of RNA isolated from brain tissue, but do not hybridize with RNA isolated from liver, spleen, kidney, heart, or lung. The RNA was just detectable after a $12 \mathrm{hr}$ exposure in the lane containing brain RNA, while no hybridization could be observed to RNA from other tissues even after a $10 \mathrm{~d}$ exposure, 



Figure 7. The F1-20 protein is distributed nonuniformly in brain. A, A sagittal section of mouse brain immunohistochemically stained with the F1-20 MAb. $B$, Hippocampus. $C$ and $D$, Striatum. $E$ and $F$, Thalamus. Abbreviations in $B: C A I-C A 3$, regions CA1-CA3 of the hippocampus; $A H$, Ammon's horn cellular layer; $o$, oriens layer; $r$, radiatum layer; $I m$, lacunosum molecular layer; $m$, molecular layer; $H$, hilus of the hippocampus; $G r D G$, dentate gyrus granule cell layer. Abbreviations in $E$ and $F: R t$, reticular thalamic nucleus; $V P L$, ventral posterolateral thalamic nucleus; str, superior thalamic radiation; $V L G$, ventrolateral geniculate nucleus; $M G$, medial geniculate nucleus; $D L G$, dorsal lateral geniculate nucleus; $S t h$, subthalamus; $Z I$, zona incerta; $L D$, laterodorsal thalamic nucleus; $A V$, anteroventral thalamic nucleus; $V L$, ventrolateral thalamic nucleus; $m l$, medial lemniscus; $R E$, retroethmoid thalamic nucleus; $P O$, posterior thalamic nuclear group; $A P T$, anterior pretectal nucleus; $P I L$, posterior intralaminar thalamic nucleus; $V P M$, ventral posteromedial thalamic nucleus; $L P$, lateral posterior thalamic nucleus. Scale bars: $A, 2$ mm; $B, 0.5$ $\mathrm{mm}$ for $B, E$, and $F ; C, 0.6 \mathrm{~mm}$ for $C$ and $D$.

indicating at least 20 -fold higher levels of F1-20 mRNA in brain versus other tissues. The restriction of mRNA expression within the brain to neuronal cells is clearly demonstrated by the in situ hybridization experiments (Fig. 5).

Expression of F1-20 mRNA and protein was found to be developmentally regulated postnatally (Fig. 6). Abrupt increases in mRNA and protein levels occur at postnatal days 4 and 7, respectively. The delay of approximately $3 \mathrm{~d}$ in the point of abrupt increase in expression of F1-20 mRNA versus protein was unexpected but is consistent with the work of Kosik et al. (1989), who also found a 2-3 d disparity between the shift to mature tau mRNA expression and mature tau protein expres- sion. The reasons for such a delayed onset of protein expression are unknown. This corresponds to the period of active synaptogenesis in the rodent CNS (Bloom, 1972). The time around P8 has been characterized as a developmental epoch in the biochemical maturation of the rodent brain (Kosik et al., 1989). The switch to the adult pattern of tau protein expression and expression of a $\mathrm{Ca}^{2+} /$ calmodulin-dependent protein kinase II kinase subunit both occur around postnatal day 8 (Kosik et al., 1989). Expression of at least one activity-dependent protein, the Cat-301 protein, has also been shown to begin postnatally and to reach adult levels within weeks, leading to the conclusion that this protein could be involved in the selection or stabili- 

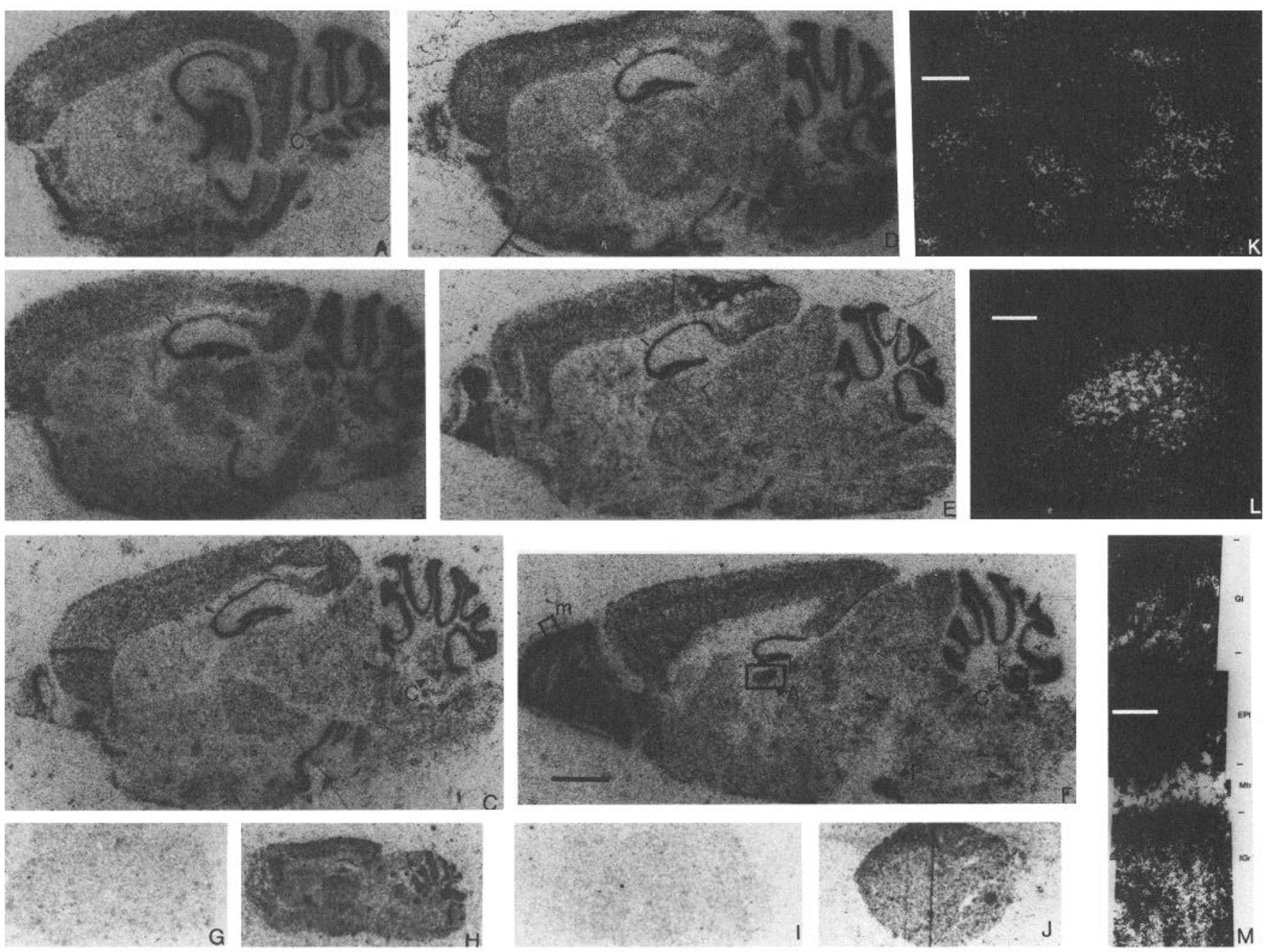

Figure 8. In situ hybridization with riboprobes transcribed from the F1-20 cDNA clone. A series of mouse brain sagittal sections are probed with ${ }^{35}$ S-labeled antisense transcripts from the F1-20 cDNA clone $(A-F)$, sense transcripts from the F1-20 cDNA clone ( $G$, negative control), and antisense transcripts from a GR cDNA clone ( $H$; positive control: compare the hybridization pattern in the Ammon's horn of the hippocampus to that observed for the F1-20 cDNA clone). Also shown are mouse liver sections probed with F1-20 antisense transcripts ( $I$ ) and GR cDNA antisense transcripts $(J)$. The bar in the hippocampal region in $A-E$ indicates the approximate position of the border between the CA1/CA2 regions of the hippocampus. Within the mes- and rhomboencephalon, a number of nuclear groups showing particularly strong hybridization with the F120 cDNA probes are evident; some of these are indicated by unlabeled arrowheads in $F$. The deep cerebellar nuclei also exhibit strong hybridization and are indicated by an arrowhead labeled $C$ in $A-D$ and $F$. Also indicated is the exceptionally strong hybridization observed in the thalamic anterodorsal (arrowhead labeled $A$ ) and pontine (labeled $P$ ) nuclear groups in $F$. Higher magnification dark-field views of emulsion dipped in situ hybridized sections taken from the boxed areas in $F$ labeled $k, l$, and $m$ are shown in $K, L$, and $M$, respectively. $G l$, glomerular layer; $E P l$, external plexiform layer; $M t r$, mitral cell layer; $I g r$, internal granular cell layer. Scale bars: $F$ (for $A-F$ ), $2 \mathrm{~mm} ; K, 50 \mathrm{~mm} ; L, 0.3 \mathrm{~mm} ; M$, $100 \mu \mathrm{m}$.

zation of the mature set of synapses on a neuron (Hockfield et al., 1983; Kalb and Hockfield, 1988; Sur et al., 1988). The regulation of F1-20 protein expression reflects this pattern of postnatal biochemical maturation of adult synaptic structures.

Within the brain, the distribution of both the F1-20 protein and the F1-20 mRNA is nonuniform (Figs. 7-9, Table 1). While the variation in F1-20 immunoreactivity is complex, we can contrast its gross features with synapsin I. For example, the strongest levels of F1-20 immunoreactivity are observed in the cortically organized regions of the brain. The lowest levels of F1-20 immunoreactivity are observed in the components of the tripartite pallidum: the globus pallidus (including the ventral pallidum), the entopeduncular nucleus, and the substantia nigra pars reticulata. In contradistinction to F1-20 immunoreactivity, synapsin I immunoreactivity in the tripartite pallidum has been shown to be quite strong and was stronger than in the molecular layers of some cortical regions (Bloom et al., 1979; De Camilli et al., 1983a). Regional variation in F1-20 mRNA expression is also complex (Figs. 8,9). In general, smaller neurons and medium-sized interneurons express reduced levels of F1-20 mRNA relative to large output neurons, even after taking into account differences in expression expected solely on the basis of cell size. There is also variation in the expression of F1-20 mRNA between different classes of large output neurons, as well as extensive variation in the expression of F1-20 mRNA between different nuclear groups. It should be noted that unlike a number of other macromolecules that have been shown to be differentially expressed in different neurons (Zipser and McKay, 1981; Hendry et al., 1984), F1-20 expression does not differentiate between otherwise identical neurons. That is, while expression of the CAT-301 protein, for example, has been shown to vary in neurons localizing to the same nucleus and that are 

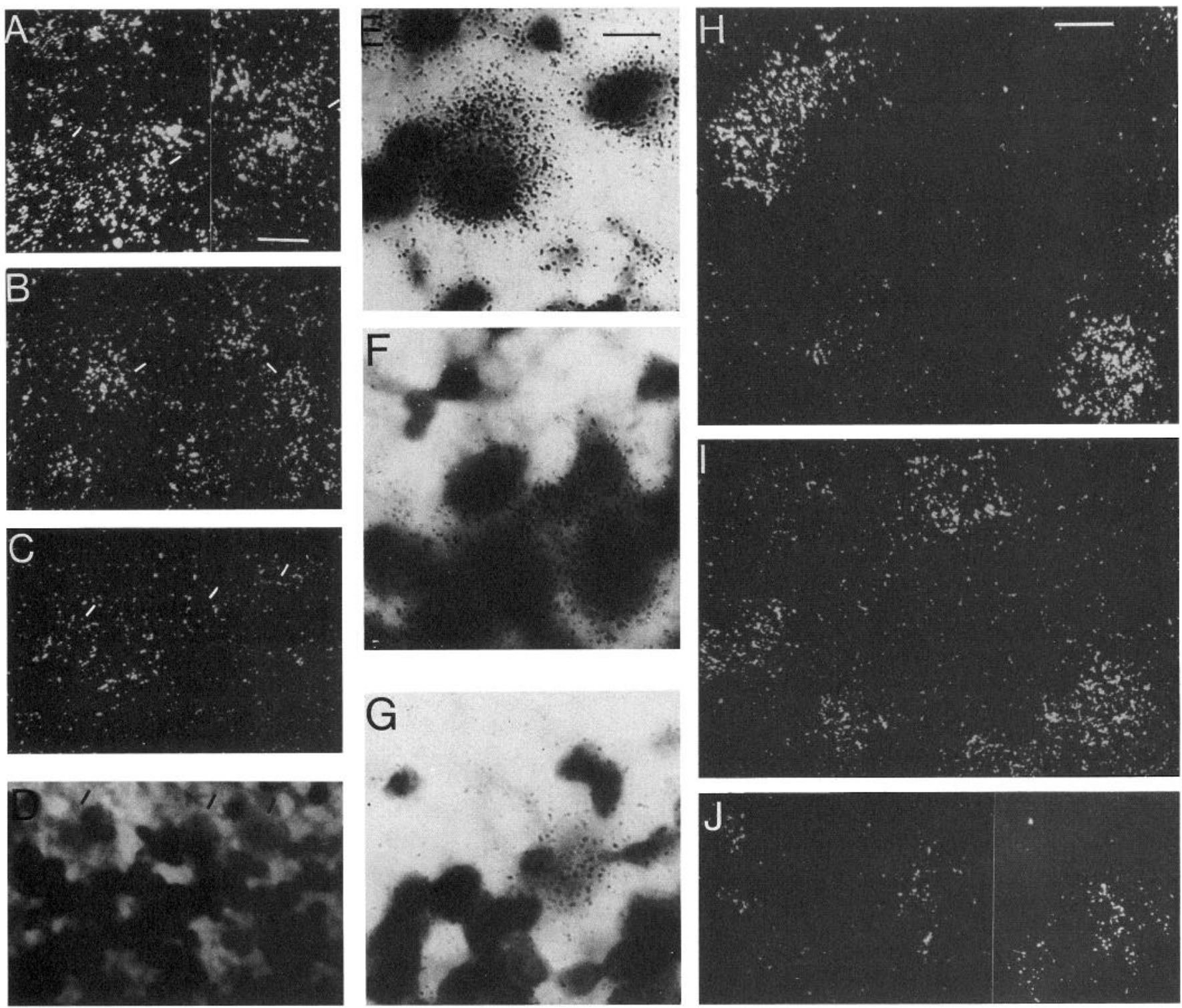

Figure 9. Variation in expression of F1-20 mRNA in cortical regions. Mouse brain sagittal sections are hybridized with ${ }^{35} \mathrm{~S}-\mathrm{labeled}$ antisense transcripts from the F1-20 cDNA clone. Variation in expression is evident in a comparison of hybridization levels in mitral cells $[A$ (dark field) and $E$ (bright field, giemsa counterstained); three mitral cells are indicated by bars in $A$ ], telencephalic pyramidal cells $(B$ and $F$; two pyramidal cells are indicated in $B$ ), and cerebellar cortex granule and Purkinje cells $(C, D$, and $G$; three Purkinje cells are indicated by bars in $C$ and $D$ ). Darkfield microscopy illustrates the variation in F1-20 mRNA in neurons of three rhomboencephalic nuclei: the gigantocellular reticular nucleus $(H)$, the reticulotegmental pons nucleus $(I)$, and the oral pontine reticular nucleus ( $J$ ). Scale bars: $A, 30 \mu \mathrm{m}$ for $A-D ; E, 20 \mu \mathrm{m}$ for $E-G ; H, 30 \mu \mathrm{m}$ for $H-J$.

otherwise morphologically indistinguishable (Hendry et al., 1988), neurons of similar morphology within a single nucleus or cortical region apparently express roughly equal levels of F120 protein and mRNA.

Axonal processes are often quite long. Consequently, one would expect that the location of a nerve terminal protein could be some distance away from the cell body that synthesized it. We note a lack of correspondence between F1-20 mRNA levels and the local concentration of the F1-20 protein. For example, the relative levels of F1-20 mRNA detected in the mes- and rhomboencephalic nuclei and the deep cerebellar nuclei by in situ hybridization are higher than the relative levels of F1-20 protein detected in these areas by immunohistochemistry. As another example, we observe that the thalamic anterodorsal nucleus displays levels of F1-20 mRNA severalfold above that of neighboring thalamic nuclei while its content of F1-20 protein is slightly below that of the neighboring thalamic nuclei. It can be concluded either that different neurons differentially regulate F1-20 mRNA translation/F1-20 protein stability, or that the major fraction of the F1-20 protein synthesized in some neurons is transported away from the cell body for considerable distances. Given the association of the F1-20 protein with synapses, the latter may be the more probable explanation.

In this article, we have presented evidence that the F1-20 protein is a novel synapse-associated, neuronal-specific protein expressed in a pattern coincident with synaptogenesis and synaptic maturation. We have also characterized the extensive variation in expression of both the F1-20 mRNA and the F1-20 
protein. In the accompanying article (Zhou et al., 1992), we have deduced the amino acid sequence for the F1-20 protein through the isolation and sequencing of overlapping cDNA clones. This led to some predictions about the biochemical properties of the F1-20 protein that then were tested. Evidence is presented that the F1-20 mRNA has two alternatively spliced isoforms, that the Fl-20 protein is a substrate for calciumdependent proteolysis that is specifically inhibited by calpain inhibitors in vitro, and that the F1-20 protein is likely to be phosphorylated in vivo.

\section{References}

Amasino RM (1986) Acceleration of nucleic acid hybridization rate by polyethylene glycol. Anal Biochem 152:304-307.

Bahler M, Klein RL, Wang JKT, Benfenati F, Greengard P (1991) A novel synaptic vesicle-associated phosphoprotein: SVAPP-120. J Neurochem 57:423-430.

Baumert M, Maycox PR, Navone F, De Camilli P, Jahn R (1989) Synaptobrevin: an integral membrane protein of 18,000 dalton present in small synaptic vesicles of rat brain. EMBO I 8:379-384.

Baumert M, Takei K, Hartinger J, Burger PM, Fischer von Mollard G, Maycox PR, DeCamilli P, Jahn R (1990) P29: a novel tyrosinephosphorylated membrane protein present in small clear vesicles of neurons and endocrine cells. J Cell Biol 110:1285-1294.

Bloom FE (1972) The formation of synaptic junctions in developing rat brain. In: Structure and function of synapses (Pappas GD, Purpura DP, eds), pp 101-120. New York: Raven.

Bloom FE, Ueda T, Battenberg E, Greengard P (1979) Immunocytochemical localization, in synapses, of protein $I$, an endogenous substrate for protein kinases in mammalian brain. Proc Natl Acad Sci USA 76:5982-5986.

Browning MD, Huang C-K, Greengard P (1987) Similarities between protein IIIa and protein IIIb, two prominent synaptic vesicle-associated phosphoproteins. J Neurosci 7:847-853.

Buckley K, Kelly RB (1985) Identification of a transmembrane glycoprotein specific for secretory vesicles of neural and endocrine cells. J Cell Biol 100:1284-1294.

Carlson SS, Kelly RB (1983) A highly antigenic proteoglycan-like component of cholinergic synaptic vesicles. J Biol Chem 258:1108211091.

Chomczynski P, Sacchi N (1987) Single-step method of RNA isolation by acid guanidinium thiocyanate-phenol-chloroform extraction. Anal Biochem 162:156-159.

Church GM, Gilbert W (1984) Genomic sequencing. Proc Natl Acad Sci USA 81:1991-1995.

De Camilli P, Cameron R, Greengard P (1983a) Synapsin I (protein I), a nerve terminal-specific phosphoprotein. I. Its general distribution in synapses of the central and peripheral nervous system demonstrated by immunofluorescence in frozen and plastic sections. J Cell Biol 96:1337-1354.

De Camilli P, Harris SM Jr, Huttner WB, Greengard P (1983b) Synapsin I (protein I), a nerve terminal-specific phosphoprotein. II. Its specific association with synaptic vesicles demonstrated by immunocytochemistry in agarose-embedded synaptosomes. J Cell Biol 96: 1355-1373.

De Camilli P, Cameron R, Greengard P (1983c) Synapsin I (protein I), a nerve terminal-specific phosphoprotein. III. Its association with synaptic vesicles studied in a highly purified synaptic vesicle preparation. J Cell Biol 96:1337-1354.

Elferink LA, Trimble WS, Scheller RH (1989) Two vesicle-associated membrane protein genes are differentially expressed in the rat central nervous system. J Biol Chem 262:11061-1 1064

Feinberg A, Vogelstein B (1983) A Technique for radiolabelling DNA restriction endonuclease fragments to high specific activity. Anal Biochem 132:6-13.

Feinberg A, Vogelstein B (1984) A technique for radiolabeling DNA restriction endonuclease fragments to high specific activity. Anal Biochem 137:266-267.

Fournier S, Trifaro J-M (1988) A similar calmodulin-binding protein expressed in chromaffin, synaptic and neurohypophyseal secretory vesicles. J Neurochem 50:27-37.

Geddes JW, Hess EJ, Hart RA, Kesslak JP, Cotman CW, Wilson MC
(1990) Lesions of the hippocampal circuitry define synaptosomalassociated protein-25 (SNAP-25) as a novel presynaptic marker. Neuroscience 38:515-525.

Gurd JW (1985) Phosphorylation of the postsynaptic density glycoprotein gp 180 by endogenous tyrosine kinase. Brain Res 333:385388.

Hahn HQ, Nichols RA, Rubin MR, Bahler M, Greengard P (1991) Induction of formation of presynaptic terminals in neuroblastoma cells by synapsin IIb. Nature 349:697-700.

Heimer L, Alheid GF, Zaborszky L (1985) Basal ganglia. In: The rat nervous system (Paxinos G, ed), pp 37-86. San Diego: Academic.

Hendry SC, Hockfield S, Jones EG, McKay R (1984) Monoclonal antibody that identifies subsets of neurones in the central visual system of monkey and cat. Nature 307:267-269.

Hendry SC, Jones EG, Hockfield S, McKay RDG (1988) Neuronal populations stained with the monoclonal antibody CAT-301 in the mammalian cerebral cortex and thalamus. J Neurosci 8:518-542.

Hockfield S, McKay RD, Henry SHC, Jones EG (1983) A surface antigen that identifies ocular dominance columns in the visual cortex and laminar features of the lateral geniculate nucleus. Cold Spring Harbor Symp Quant Biol 48:877-889.

Hughes JH, Mack K. Hamparian VV (1988) India ink staining of proteins on nylon and hydrophobic membranes. Anal Biochem 173: $18-25$.

Huttner WB, Schiebler W, Greengard P, De Camilli P (1983) Synapsin I (protein I), a nerve terminal-specific phosphoprotein. III. Its association with synaptic vesicles studied in a highly purified synaptic vesicle preparation. J Cell Biol 96:1374-1388.

Israel M, Morel N, Lesbats B, Birman S, Manaranche R (1986) Purification of a presynaptic membrane protein that mediates a calciumdependent translocation of acetylcholine. Proc Natl Acad Sci USA 83:9226-9230.

Jahn R, Schiebler W, Ouimet C, Greengard P (1985) A 38,000-dalton membrane protein $(\mathrm{p} 38)$ present in synaptic vesicles. Proc Natl Acad Sci USA 82:4137-4141.

Kalb RG, Hockfield S (1988) Molecular evidence for early activitydependent development of hamster motor neurons. J Neurosci 45: 86-94.

Knaus P, Marqueze-Pouey B, Scherer H, Betz H (1990) Synaptoporin, a novel putative channel protein of synaptic vesicles. Neuron $5: 453-$ 462.

Kohtz DS, Puszkin S (1988) A neuronal protein (NP185) associated with clathrin-coated vesicles. J Biol Chem 263:7418-7425.

Kosik KS, Orecchio LD, Bakalis S, Neve RL (1989) Developmentally regulated expression of specific tau sequences. Neuron 2:1389-1397.

Lafer EM, Sousa RJ, Rich A (1988) Z-DNA-binding proteins in $E s-$ cherichia coli: purification, generation of monoclonal antibodies and gene isolation. J Mol Biol 203:511-516.

Lehrach H, Diamond D, Wozney JM, Boedtker H (1977) RNA molecular weight determinations by gel electrophoresis under denaturing conditions, a critical reexamination. Biochemistry 16:4743-4751.

Linial M, Miller K, Scheller RH (1989) VAT-1: an abundant membrane protein from Torpedo cholinergic synaptic vesicles. Neuron 2: $1265-1273$.

Llinas R, McGuiness TL, Leonard CS, Sugimori M, Greengard P (1985) Intraterminal injection of synapsin I or calcium/calmodulin-dependent protein kinase II alters neurotransmitter release at the giant squid synapse. Proc Natl Acad Sci USA 82:3035-3039.

Maroteaux L, Campanelli JT, Scheller RH (1988) Synuclein: a neuronspecific protein localized to the nucleus and presynaptic nerve terminal. J Neurosci 8:2804-2815.

Matthew WD, Tsavaler L, Reichardt LF (1981) Identification of a synaptic vesicle-specific membrane protein with a wide distribution in neuronal and neurosecretory tissue. J Cell Biol 91:257-269.

Oyler GA, Higgins GA, Hart HA, Battenberg F, Billingsley M, Bloom FE, Wilson MC (1989) The identification of a novel synaptosomalassociated protein, SNAP-25, differentially expressed by neuronal subpopulations. J Cell Biol 109:3039-3052.

Paxinos G, Watson C (1986) The rat brain in stereotaxic coordinates. San Diego: Academic.

Perin MS, Fried VA, Mignery GA, Jahn R, Sudhof TC (1990) Phospholipid binding by a synaptic vesicle protein homologous to the regulatory region of protein kinase $C$. Nature 345:260-263.

Petrenko AG, Perin MS, Davletov BA, Ushkaryov YA, Geppert M, Sudhof TC (1991) Binding of synaptotagmin to the $\alpha$-latrotoxin 
receptor implicates both in synaptic vesicle exocytosis. Nature 353: 65-68.

Pfeffer SR, Kelly RB (1985) The subpopulation of brain coated vesicles that carries synaptic vesicle proteins contains two unique polypeptides. Cell 40:949-957.

Ritchie TC, Thomas MA, Coulter JD (1989) A nerve terminal protein with a selective distribution in spinal cord and brain. J Neurosci 9: 2697-2709.

Sousa RJ, Hrinya Tannery N, Lafer EM (1989) In situ hybridization mapping of glucocorticoid receptor messenger RNA in rat brain. Mol Endocrinol 3:481-494.

Sousa RJ, Hrinya Tannery N, Lafer EM (1990) Two new monoclonal antibodies provide immunohistochemical evidence for the unique biochemical similarity of the mouse globus pallidus, entopeduncular nucleus, and substantia nigra pars reticulata. Neuroscience 34:403410.

Su B, Hanson V, Perry D, Puszkin S (1991) Neuronal specific protein 185 is enriched in nerve endings: binding characteristics for clathrin light chains, synaptic vesicles, and synaptosomal plasma membrane. J Neurosci Res 29:461-473.

Sudhof TC, Jahn R (1991) Proteins of synaptic vesicles involved in exocytosis and membrane recycling. Neuron 6:665-677.

Sudhof TC, Baumert M, Perrin MS, Jahn R (1989a) A synaptic vesicle membrane protein is conserved from mammals to Drosophila. Neuron 2:1475-1481.

Sudhof TC, Czernik AJ, Kao H-T, Takei K, Johnston PA, Horiuchi A, Kanazir SD, Wagner MA, Perin MS, De Camilli P, Greengard P (1989b) Synapsins: mosaics of shared and individual domains in a family of synaptic vesicle phosphoproteins. Science 245:1474-1480.

Sur M, Frost DO, Hockfield S (1988) Expression of a cell surface antigen on $\mathrm{Y}$-cells in the cat lateral geniculate nucleus is regulated by visual experience. J Neurosci 8:874-882.

Thomas L, Betz H (1990) Synaptophysin binds to physophilin, a putative synaptic plasma membrane protein. J Cell Biol 111:20412052.

Thomas L, Hartung K, Langosch D, Rehm H, Bamberg E, Franke WW, Betz H (1988) Identification of synaptophysin as a hexameric channel protein of the synaptic vesicle membrane. Science 242:1050-1053.

Trimble WS, Cowan DM, Scheller RH (1988) VAMP-1: a synaptic vesicle-associated integral membrane protein. Proc Natl Acad Sci USA 85:4538-4542.

Trimble WS, Gray TS, Elferink LA, Wilson MC, Scheller RH (1990) Distinct patterns of expression of two VAMP genes within the rat brain. J Neurosci 10:1380-1387.

Trimble WS, Linial M, Scheller RH (1991) Cellular and molecular biology of the presynaptic nerve terminal. Annu Rev Neurosci 14: 93-122.

Vaughn JE (1989) Review: fine structure of synaptogenesis in the vertebrate central nervous system. Synapse 3:255-285.

Walaas I (1983) The hippocampus. In: Chemical neuroanatomy (Emson PC, ed), pp 337-358. New York: Raven.

Wiedenmann B, Franke WW (1985) Identification and localization of synaptophysin, an integral membrane glycoprotein of $M_{r} 38,000$ characteristic of presynaptic vesicles. Cell 41:1017-1028.

Zhou S, Sousa R, Hrinya Tannery N, Lafer EM (1992) Characterization of a novel synapse-specific protein. II. cDNA cloning and sequence analysis of the F1-20 protein. J Neurosci 12:2144-2155.

Zipser B, McKay R (1981) Monoclonal antibodies distinguish identifiable neurones in the leech. Nature 289:549-554. 